\title{
Comparative Leaf Anatomy of Selected Species in Vitaceae and Leeaceae
}

\author{
Chnar Najmaddin, Khatijah Hussin and Haja Maideen \\ School of Environmental Science and Natural Resource, \\ Faculty of Science and Technology, University Kebangsaan Malaysia, Bangi, Selangor, Malaysia
}

Received 2012-06-05, Revised 2012-09-03; Accepted 2013-05-15

\begin{abstract}
Leea species was originally placed in the family Vitaceae but was later placed in the Leeaceae due to the anatomical differences between the two families and between species. A study on the anatomical difference in leaves of four species in the Vitaceae (Tetrastigma cruciatum, Pterisanthes miquelii, Cissus hastata and Nothocissus spicifera) and two species from Leeaceae (Leea rubra and Leea indica) was undertaken. Show that species from the two families differ in the shape of the transverse sections of the petiole and midrib. Druses and raphides are present in the petioles and midribs of Tetrastigma cruciatum, Pterisanthes miquelii, Cissus hastata and Nothocissus spicifera, while in Leea rubra and Leea indica only druses are present. Starch grains are present in the pith of the Vitaceae species studied but are absent in both L. rubra and L. indica.
\end{abstract}

Keywords: Leaf Anatomy, Vitaceae, Leea Sp. Anatomy of Vitis Vinifera Leaf

\section{INTRODUCTION}

Vitaceae, the grape family, contains around 700 species, assigned to 13-15 genera and are mostly lianas distributed in tropical and temperate areas throughout the world (Chen and Manchester, 2007; Lombardi, 2007). Leafopposed tendrils, inflorescences and the unique seed morphology are the most useful characters to distinguish Vitaceae from other families. Morphologically the Vitaceae family is well delimited and easily recognized. The genera are delimited by floral morphology, inflorescence types and sometimes seed morphology (Chen and Manchester, 2007). Leeaceae was formerly a part of the Vitaceae in the subfamily Leeoideae but due to morphological differences is now placed in it is own family (Steven, 2000). Members of this family which has approximately 70 species are mostly shrubs, small trees, scramblers, or rarely large perennial herbs bearing terminal inflorescences with hermaphroditic flowers and distinct wood anatomical characters (Wen, 2007b). Stems of Leeaceae are unarmed or with rows of prickles but with an absence of tendrils unlike Vitaceae (Chen et al., 2007; Wen, 2007b). This study was undertaken to investigate the anatomical difference in leaves of selected species in the Vitaceae and Leeaceae in order to see whether sterile specimens can be used to identify the families.

\section{MATERIALS AND METHODS}

Plant materials were collected from the field in Malaysia and fixed in a mixture of alcohol and glacial acetic acid. Transverse sections through the middle region of petioles and midribs were made on the sliding microtome (Richard Jung or Leica Histolide 200) and stained in Safranin and Alcian Green. Following dehydration in an alcohol series the sections were mounted in Euparal (Johansen, 1940). Images were captured using a Video Camera (JVC) attached to a leica diaplan microscope using analysis docu software.

\section{RESULTS}

\subsection{Leaf Anatomy in Transverse Sections}

\subsubsection{TS Petiole}

In Vitaceae the outline in TS is different between species. It varies from subcircular with concave adaxial surfaces as in P. miquelii, C. hastata and N. spicifera while in $T$. cruciatum the abaxial surface is rounded and the adaxial surface convex with rounded lateral projections. Collenchyma cells are present in the cortex beneath the epidermis in T. cruciatum, P. miquelii and N. spicifera.

Corresponding Author: Chnar Najmaddin, School of Environmental Science and Natural Resource,

Faculty of Science and Technology, 43650, University Kebangsaan Malaysia, Bangi, Selangor, Malaysia 


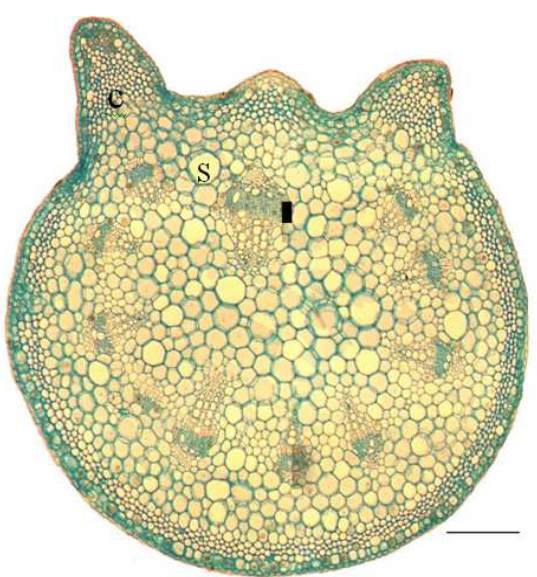

(A)

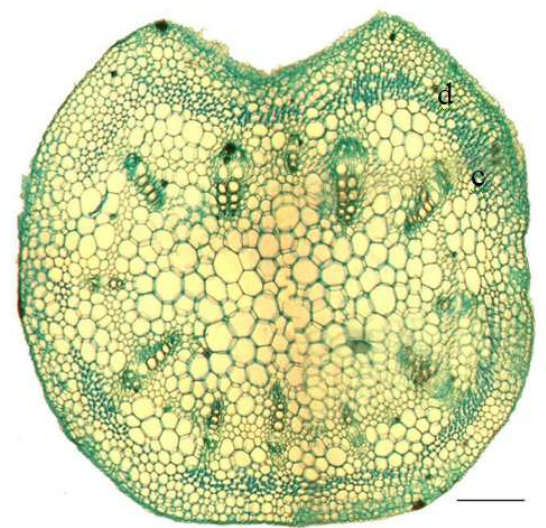

(C)

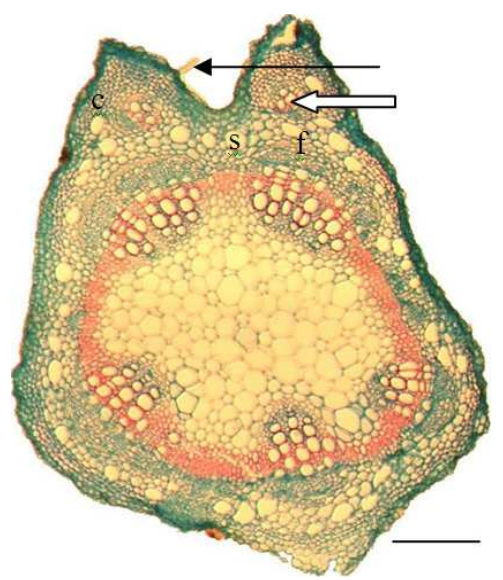

(E)

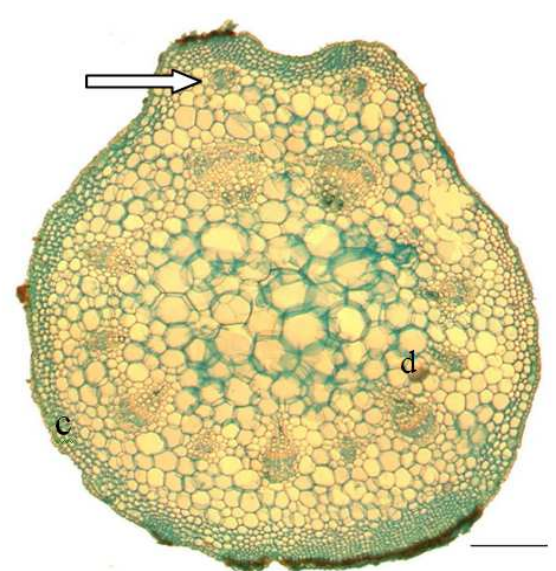

(B)

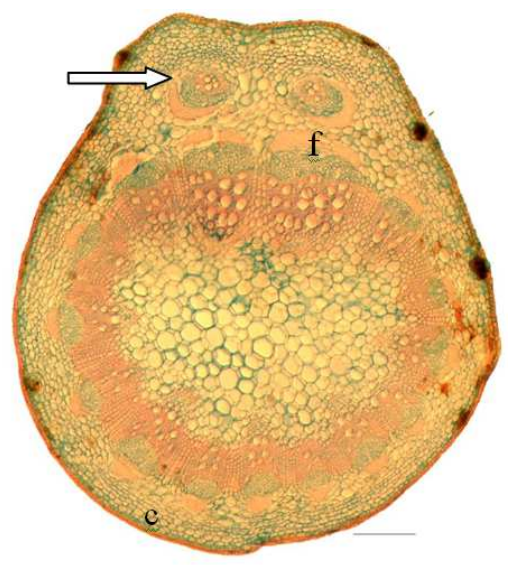

(D)

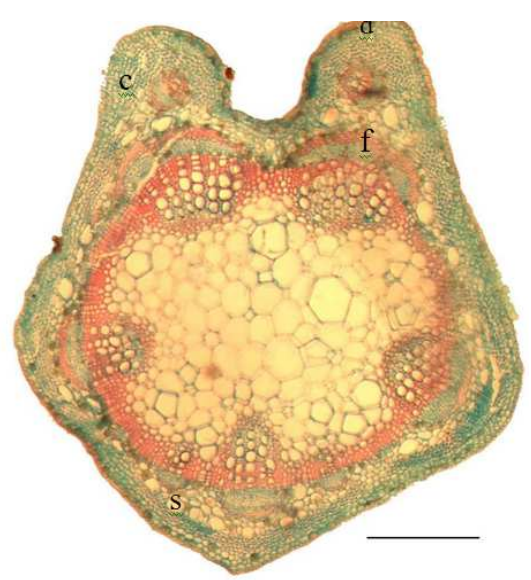

(F)

Fig. 1. TS of petioles. (A) Tetrastigma cruciatum petiole. (B) Pterisanthes miquelii. (C) Cissus hastate. (D) Nothocissus spicifera. (E) Leea rubra. (F) Leea indica, s: secretory canal, c: collenchyma cells, d: druses, accessory vascular bundle (white arrow), f: fibers, simple unicellular trichome (black arrow). Scale: A, B, C, D and F $=500 \mu \mathrm{m} ; \mathrm{E}=200 \mu \mathrm{m}$ 


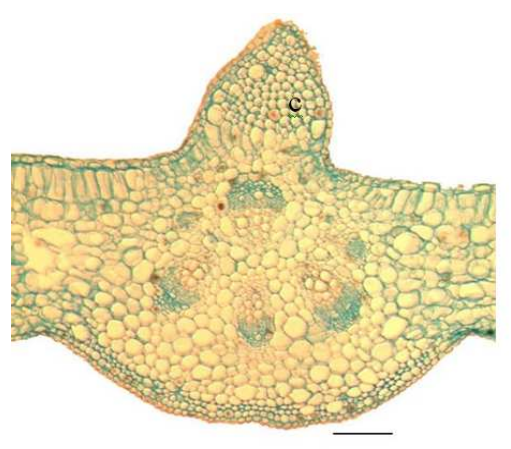

(A)

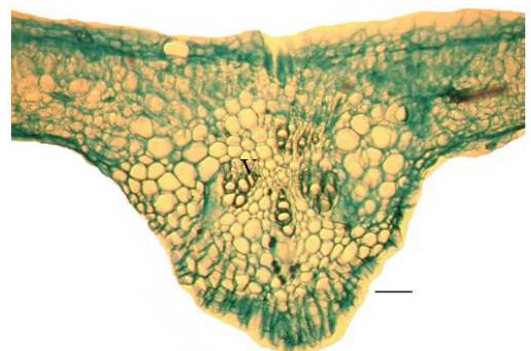

(C)

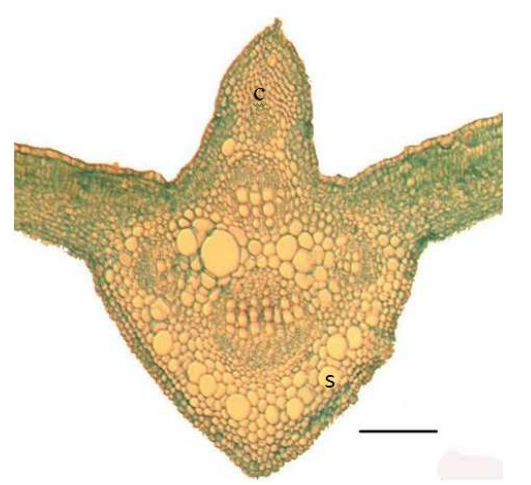

(E)

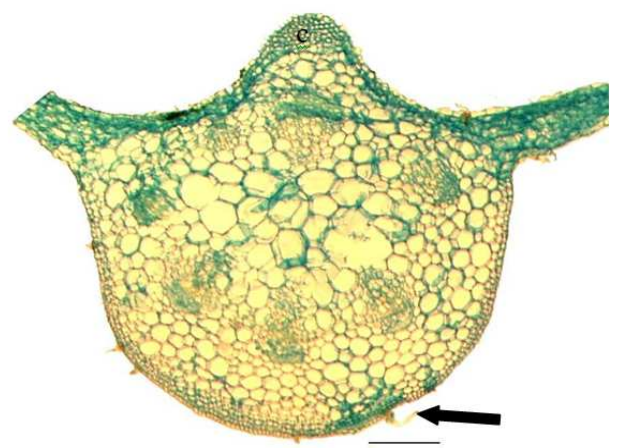

(B)

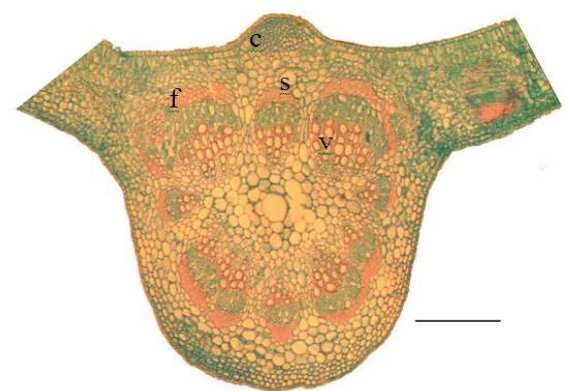

(D)

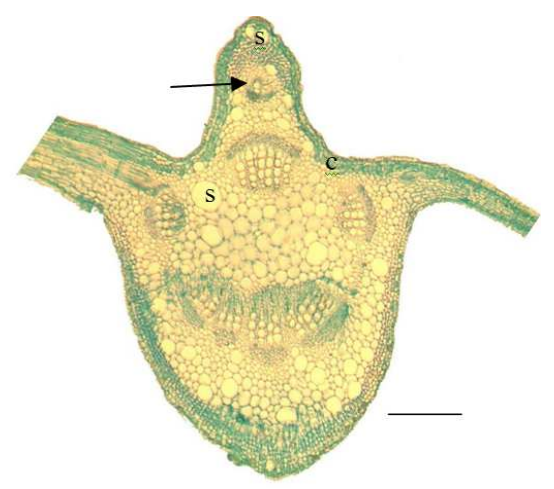

(F)

Fig. 2. TS of midrib. (A) Tetrastigma cruciatum. (B) Pterisanthes miquelii. (C) Cissus hastate. (D) Nothocissus spicifera. (E) Leea rubra. (F) Leea indica, c: collenchyma cells, s: secretory cells, f: fibers, accessory vascular bundle (small black arrow), v: vascular bundle, unicellular non glandular trichome (large black arrow). Scale: A, C, E and F = $200 \mu \mathrm{m}$; B and D = $500 \mu \mathrm{m}$

In C. hastata on the other hand, these cells occur below approximately five layers of parenchyma cells from the epidermis. The vascular tissue is of the closed type and surrounded by a fibrous layer. Both raphides and druses are present in the ground tissue of the vascular bundle in all species (Fig. 1 A-D). Secretory cells are present in the ground tissue of all species while starch grains are only present in the pith of $T$. cruciatum but absent in the rest of the species.
In both Leea species the adaxial surface of the petiole is concave in TS with humps on both sides while the abaxial surface is 'V' shape. Simple unicellular trichomes are present in L. rubra but absent in L. indica. Collenchyma cells are present in the cortex beneath epidermal layer in both species. The vascular tissue system is similar to that of Vitaceae which is closed and surrounded by a fiber layer occurring as bundle caps. Druses, secretory cells and accessory vascular bundles are present in both species (Fig. $1 \mathrm{E}$ and F). 


\subsection{TS Midrib}

The outline of the midrib of Vitaceae varies between species. The adaxial surface is convex, while the abaxial surface is arc shape as in $T$. Cruciatum. In P. miquelii the adaxial surface has a pointed hump, while the abaxial surface is rounded. In adaxial surface $C$. hastata is the nearly straight and the abaxial surface is ' $\mathrm{V}$ ' shape, while the adaxial surface of $N$. spicifera has a small hump with the abaxial surface is ' $U$ ' shape. Simple, unicellular non glandular trichomes are present in $P$. miquelii (Fig. 2 A-D). In Leeaceae the adaxial surface has an oblong hump in both species, while the abaxial surface vary from ' $U$ ' shape as in L. rubra to ' $\mathrm{V}$ ' shape as in L. indica. The vascular tissue in both families is of the closed type with accessory vascular bundles occurring in L. indica (Fig. 2 E and F). Only druses are present near the vascular bundles in Leeaceae.

\section{DISCUSSION}

Leeaceae is most closely related to Vitaceae but most workers have now separated it from Vitaceae (Wen, 2007a). In contrast to Vitaceae, Leeaceae is characterized by the highly distinctive flowers, the absence of tendrils, the terminal inflorescence, distinct wood anatomical characters, usual stipular structure and the erect habit (Wen, 2007b). The present study shows that both Leeaceae and Vitaceae possess common characters such as the presence of druses and secretory cells. Secretory cells with amorphous contents which are probably mucilaginous and tanniniferous are widely distributed in the parenchymatous tissues and has also been found in Leea angulata (Metcalfe and Chalk, 1950). Leeaceae and Vitaceae however, can be differentiated easily by the absence of raphides in the former such as has been reported by (Metcalfe and Chalk, 1950).

Collenchyma tissues are present in the petiole and usually occurr as a wide band below the epidermis, appearing very conspicously in Petrisanthas, Tetrastigma and Northoscissus. In Cissus hastate however it is not well developed such as was observed in Cayratia, where it occur in isolated patches, particularly obvious in Cayratia japonica and Cayratia trifolia (Latiff, 1980).

This investigation has also shown that the presence or absence of trichomes can differ between the two families or within the family. As an example, their presence in Leea rubra petioles can differentiate this species from Leea indica. According to Lambardi (2007) this characteristic is useful for species identification.

The outline of the petiole and midrib in transverse sections differ between species in the two families. In addition to this the presence of accessory bundles are also useful for species identification. Results of this investigation thus show that a combination of several characters is useful for species identification and confirmation.
A more comprehensive study on more species of the two families is suggested that would provide conclusive evidence of good anatomical characters for species differentiation in the Vitaceae and Leeaceae especially in the absence of floral materials.

\section{CONCLUSION}

The results conclude that starch grains are present in the pith of the Vitaceae species studied but are absent in both L. rubra and L. indica.

\section{ACKNOWLEGEMENT}

I would like to thank Samiah Kadri and Mohd. Ruzi for their technical assistance. We wish to express our gratitude to the Universiti Kebangsaan Malaysia for financial support via FRGS grant UKM-ST-08FRGS0013-2009.

\section{REFERENCES}

Chen, I. and S.R. Manchester, 2007. Seed morphology of modern and fossil Ampelocissus (Vitaceae) and implications for phytogeography. Am. J. Bot., 94: 1534-1553. DOI: 10.3732/ajb.94.9.1534

Chen, Z., Ren, H. and Wen, 2007. Vitaceae. Flora of china. Published by Science press (Beijing) and Missouri Botanical Garden press. FOC. 12: 115-173.

Johansen, D.A., 1940. Plant Microtechnique. 1st Edn., McGraw-Hill Book Company, New York, pp: 523.

Lambardi, D., F.R. Dani, S. Turillazzi and J.J. Boomsma, 2007. Chemical mimicry in an incipient leaf-cutting ant social parasite. Behavioral Ecology Sociobiol., 61: 843-851. DOI: 10.1007/s00265-006-0313-y

Latiff, A.A., 1980. Petiole anatomy of some species of malesian vitaceae. Sains Malays. J. Nat. Sci., 9: 191-202.

Lombardi, J., 2007. Systematics of vitaceae in south america. Canadian J. Bot., 85: 712-721. DOI: 10.1139/B07-021

Metcalfe, C.R. and L. Chalk, 1950. Anatomy of the Dicotyledons. 1st Edn., Clarendon Press, Oxford, pp: 724.

Steven, P., 2000. Vitaceae. Angiosperm phylogeny website.

Wen, J., 2007a. The Families and Genera of Vascular Plants: Vitaceae. 1st Edn., Springer-Verlag Berlin, Heidelberg, pp: 467.

Wen, J., 2007b. The Families and Genera of Vascular Plants. 1st Edn., Springer-Verlag Berlin, Heidelberg, pp: 225. 